\title{
Research on Measurement and Use of Customer Value and Loyalty
}

Xiaobin Zhou

\author{
Michigan State University \\ 426 Auditorium Rd, East Lansing, MI 48824 \\ Corresponding Author's Email:13857109118@163.com
}

\begin{abstract}
This paper aims at determining how customer value and loyalty are measured. The paper relied on previous literature to attain the perceived results. From past literature, the measurement of customer loyalty and value is subjective because of human attributes such as attitude and behavior. It is therefore complicated in doing a survey that will be conclusive. However, from the study, it was deduced that customer loyalty can be determined if a company understands past loyalty experience that will be used to predict future customer loyalty. Customer value on the other hand can be measured based on the cost associated with acquiring a customer and the customer turnover in a given period.
\end{abstract}

Keywords: Measurement, Customer, Value, Loyalty

\section{INTRODUCTION}

Customer loyalty and value play a key role in assuring a company of competitive advantage since it is cheaper to main loyal customers than to acquire new customers. Developing and maintaining customer loyalty and value has become an important exercise for companies that have identified its benefits[1]. However, it is quite difficult to develop customer loyalty and value without measuring it. This paper is dedicated to defining how customer loyalty and value is measured before it is developed.

\section{CUSTOMER VALUE}

Customer value is explained from two main perspectives. Firstly, customer value is all about a customer's financial value. Secondly, customer value can be viewed that customer gets from an organization. From the financial perspective, customer value is viewed as the total sum of pennies an organization spends on a customer. Customer value from the customer perspective tries to explain how much and what extend will an organization deliver given its promises to the customer[2]. A customer thinks of the price versus quality, the service provided, and if the solution offered by an organization meets customer expectations. There is a tension between the customer and the company's customer value. For instance, a company could need to satisfy its customers as much as possible. Unfortunately, the employees are not committed to delivering the services as required by the customers.

To determine or measure customer value will enable a company to get an insight into the product now and in the future. Inappropriate customer measurement could lead a company into making unexpected losses. Measuring customer value can make an organization make adjustments for improving the predictability of the business and determine the future margin. Three main areas of absolute importance when measuring customer value include predictable value, financial value and soft value and it contains three steps.

The first step in measuring customer value is to determine a customer's financial value. An organization can determine customer financial value by considering costs and turnover [3]. A company should evaluate the marketing costs that can be used to satisfy the targeted customer. Marketing costs can be attributed to the customer directly and they include costs attributed to business gifts to the customer, costs incurred during events, and costs incurred during e-mail and content campaigns. The company should also determine account or service fees attributable to logistics and customer service which are also used to determine customer 
satisfaction. Service fees can be determined by taking the percentage of wages that the service and account workforce earn. Recruitment costs incur when acquiring a customer. A company should understand how it acquired a customer and the costs it incurs to get that customer. The total costs attributable to customer value can be compiled reasonably and easily by using Marketing Automation System. Cokins (2017) researched to investigate how the best cost can be calculated to find the best "hard figures" associated with customer loyalty. It was discovered that various cost models can be used to determine costs aligned to customer value. A model such as ABC employs multiple stages to segment and trace resource expenditures using cost assignment networks into final costs linked to customer value[4].

Predictable customer value is simply mapping up future customer value. Customers staying loyal to a company for over five years generate more turnover when compared to a customer who stays in a company for a while and turns to a competitor. Predictable customer value is done by segmenting customers according to their buying patterns and purchasing behavior[5]. During customer segmentation, three values are imminent: the frequency of a customer making a purchase, the recent time the customer made a purchase, and the monetary value associated with the purchases. The segmentation enables the company to determine average buyers, recent buyers as well as the customer with no purchasing record for over a year. The segments are then analyzed to understand the degree of customer loyalty for a customer and then the information can be used to determine the customer's future value, lifetime value as well as churn. The information will further be used to understand if the company is on the verge of collapse or growing or if financially stable and also the challenges that it is going to face in the future.

Soft customer values relate to the values that cannot be associated with "hard figures". Soft customer values can be mapped by contacting the company customers. Customer satisfaction is a soft customer value that can be mapped through a Net Promoter Score (NPS) where a company can ask a customer if they would recommend the company to them or they have a good experience with the company[6]. Customer experience is another soft customer value that can be evaluated between quantitative and qualitative studies with company customers. The company can ask how the service satisfies them, how they think about the company's brand image and it is a necessity for improvement.

\section{CUSTOMER LOYALTY}

According to marketing literature, loyalty is behavioral and attitudinal, or affective, cognitive, action and conative. Claudia, Gatej, and Ciobanu (2015) conducted qualitative and quantitative studies on cosmetic companies to understand whether a loyalty scale can be effective in marketing. It was deduced that the loyalty scale involves affective, action and conative loyalty and that the scale is the best in measuring loyalty in the direct sales cosmetic industry[7]. From a strategic perspective, customer relationship management links customer strategies with business processes to create customer loyalty as well as increasing profitability in the long-run. Measuring customer loyalty is sometimes complex because customer attitudes and behavior are involved. Some of the expected behavior and attitude that define customer loyalty include; The probability of a customer recommending a company's products to other potential customers. A research that was conducted by Nyarko et al (2016), based on an interpretive literature methodology to investigate how customer loyalty is measured using advocacy, patronage and retention. It was discovered that customer loyalty is complex to measure since the proof of loyalty as well as the loyalty state is exposed after the occurrence of an action that defines an individual's loyalty. It is however perceived that past customer loyalty can indicate but does not guarantee customer loyalty in the future[8].

\section{CASE STUDY}

From the various studies, customer value can be measured in monetary terms where customer loyalty tends to be complex to measure because it involved an individual's behavior and attitudes. Through qualitative and quantitative studies, it was deduced that affective, action and conative are associated with customer loyalty. From a pool of literature customer value can be viewed from the perspective of the customer or the perspective of the company. It is discovered that customer value can be measured in terms of costs and turnover. Costs include all the expenditures that the company used to acquire loyal customers. The total costs associated with customer loyalty can best be calculated using the ABC model where various stages are used to trace resource expenses that are compiled to produce the final cost. The literature identifies that customer loyalty and customer value are important for a company, yet measuring them can be subjective because of other human attributes such as human behavior and attitude. 


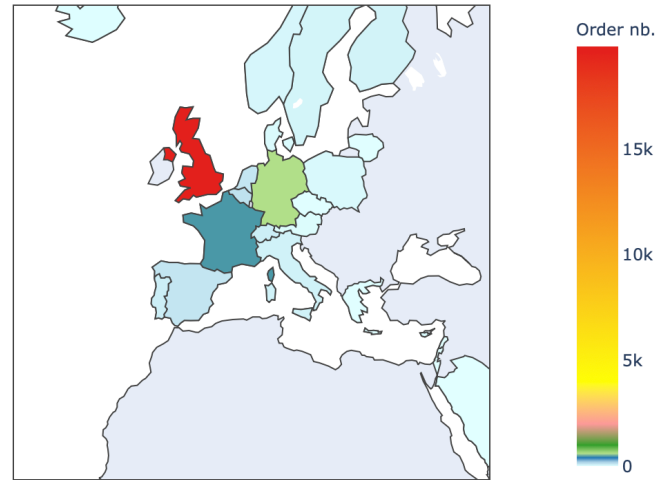

Figure 1. The Number of orders per country

In our project, we choose to classify customers by various user characteristics. In figure 1 , we can see the number of countries in the data is 37 , and the dataset is largely dominated by orders made from the UK. In figure 2, we can see the majority of order amounts are between $£ 200$ to $£ 500$, and most order amounts are below $£ 5000$.

\section{Distribution of order amounts}

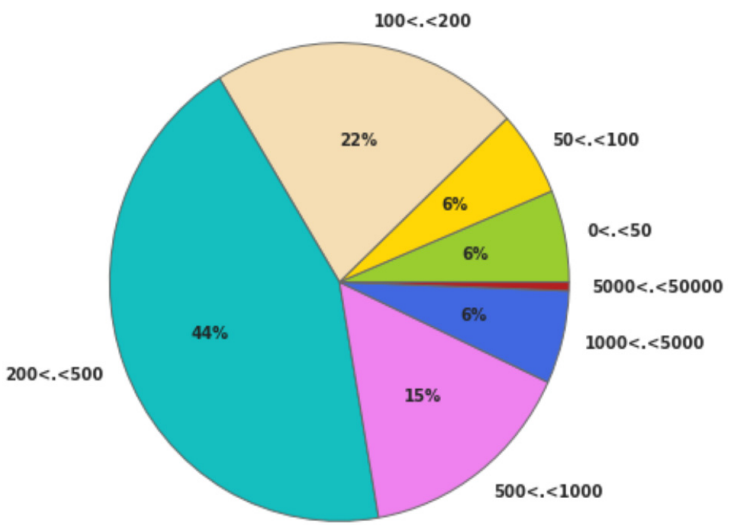

Figure 2. Distribution of order amounts[11]

This data encoding identifies three main keywords in order to create groups of products. In figure 3, the products are clustered into three different classes. Hamming's metric is used for the calculation of distances to define the approximate number of clusters that represent the data. Here is the silhouette score. Also, the score for five clusters recorded scores of $0.1 \pm 0.05$ obtained from all the clusters. Beyond five clusters, some had few elements and thus the database had to be separated 5 clusters.

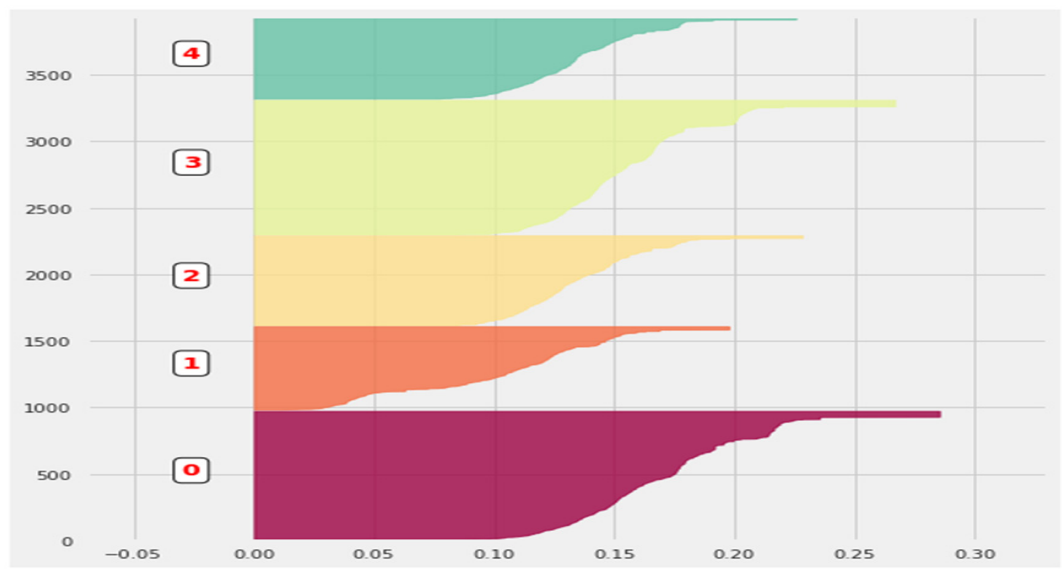

Figure 3. Sihouette intra-cluster score for the dataset

In figure 4, the word cloud is used in the determination of the types of objects that the clusters represent, and a global view of the contents is determined by assessing the frequent keywords. In conclusion, the first cluster is the gifts with keywords: wrap, packaging, Christmas and card. The second cluster is luxury items and jewelry with keywords: necklace, lace and silver. The third cluster is household products with keywords: candle, bottle, box, pan and cushion. 

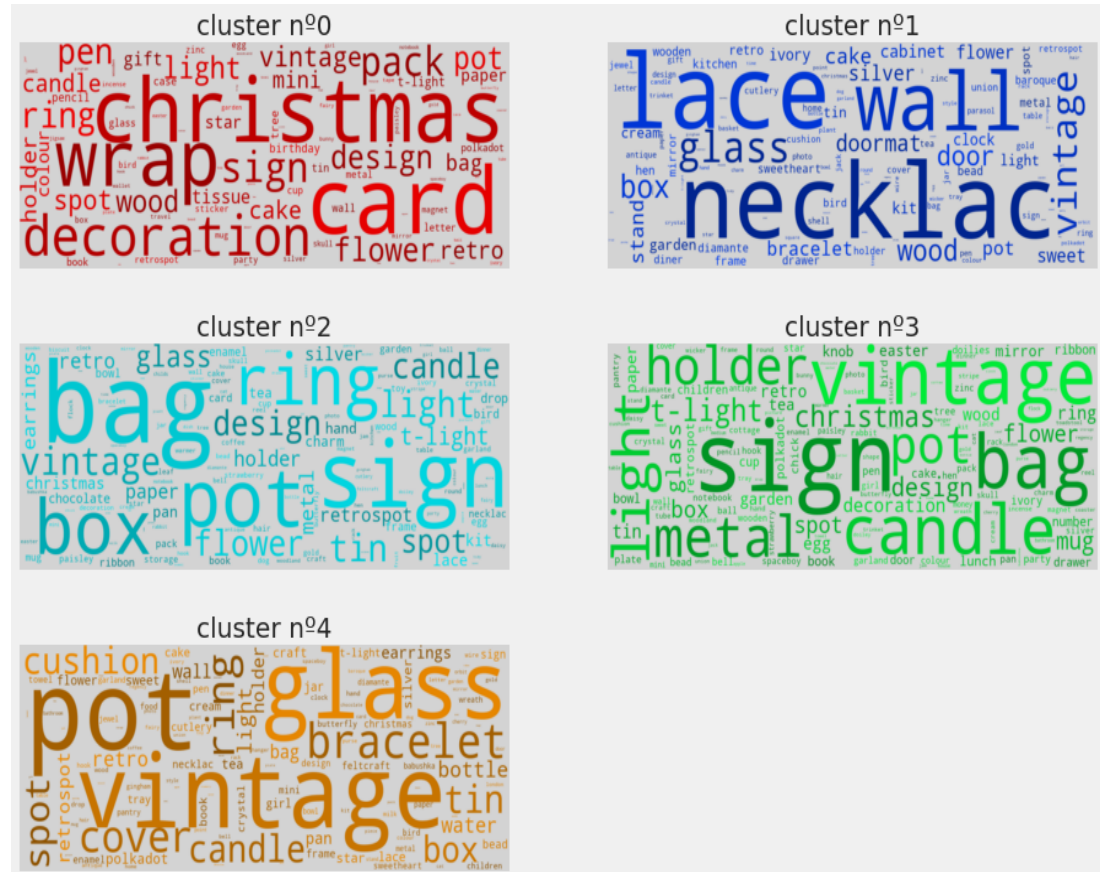

Figure 4. Word cloud for the dataset

In figure 5, some methods such as Support Vector Machine, Logistic regression, K-nearest Neighbors, Decision Tree, Random Forest and Gradient Boosting were respectively used to analyze the data in the previous ten months and predict the data in the next two months. The actual data for the last two months were then compared with those predicted by the model. This way is used to determine the quality of the predictions of the different classifiers over the last two months of the dataset.

\section{Testing predictions}

\begin{tabular}{|l|l|l|}
\hline Classifier & Precision in the classifier part & Precision in current part \\
\hline Support Vector Machine & $83.6 \%$ & $70.36 \%$ \\
\hline Logistic Regression & $87.18 \%$ & $74.28 \%$ \\
\hline K-Nearest Neighbors & $81.06 \%$ & $71.11 \%$ \\
\hline Decision Tree & $82.91 \%$ & $76.68 \%$ \\
\hline Random Forest & $90.76 \%$ & $78.79 \%$ \\
\hline Gradient Boosting Classifier & $90.18 \%$ & $77.58 \%$ \\
\hline
\end{tabular}

Figure 5. The predictions value of six different methods

The prediction in Voting Classifier Method, mix Random Forest, Gradient Boosting and K-nearest Neighbor leads to a slight improvement in predictions. Moreover, differences were compared between the previous data and the data in this part. 


\section{Testing predictions}

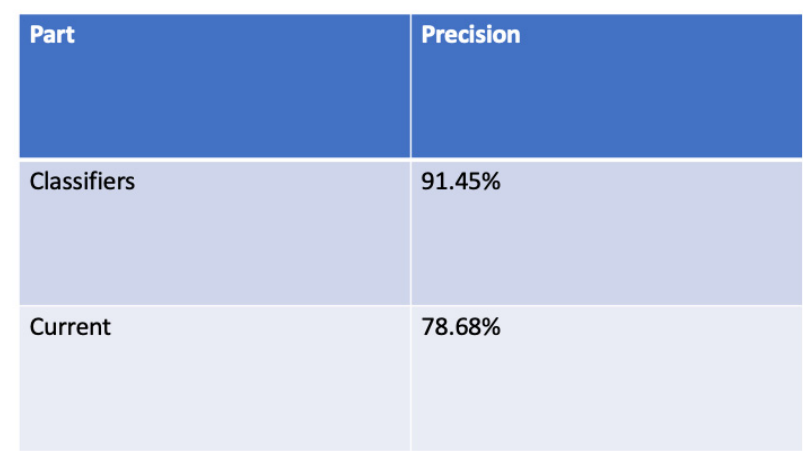

Figure 6. Testing predictions

\section{CONCLUSION}

Customer value and customer loyalty can measure the same way although customer value is attached to hard figures while customer loyalty is subjective because of human attributes involved. Customer value is measured in monetary terms. The research shows that for a company to project future profits, it should measure customer value and loyalty now so as to determine the future. From the literature, customer value can be viewed from the perspective of the customer or the perspective of the company. A well measured customer loyalty and value can lead to good future profitability. In this project, we want to develop a classifier by analyzing a database with more than 4,000 customer information, which can test the type of purchase a customer will make and the number of visits in the next year. In the end, a classifier is produced with an accuracy of about $75 \%$.

\section{ACKNOWLEDGMENT}

Many thanks to Professor Stephen Coggeshall for the advice and help provided during the writing of this paper.

\section{REFERENCES}

[1] Abu-Alhaija, A., S. Yusof, R., N, Hasim, H., and Jaharuddin, N., S. "Determinants of Customer Loyalty: A Review and Future Directions," Australian Journal of Basic and Applied Sciences, Vol. 12, No 7, pp 106-111, 2018.

[2] Bermejo, G., and Monroy C., R. "How to measure customer value and its relationship with shareholder value in a business-to-business market," Intangible Capital, Vol. 6, No. 2, pp 142$161,2010$.

[3] Epstein, M., J. and Yuthas, K. "Managing Customer Value," Strategic Measurement, 2007

[4] Cokins, G. "Measuring and Managing Customer Profitability," Strategic Finance, 2017

[5] Khadka, K., and Maharjan, S., "customer satisfaction and customer loyalty," Business Management, November 2017.

[6] White, K., S. "What is a Net Promoter Score (NPS)? A simple metric to gauge customer loyalty," CIO, 2018.

[7] Claudia, B., Gatej, C., and Ciobanu, O. "Developing a scale to measure customer loyalty," Procedia Economics and Finance 3, pp 623 - 628, 2012.

[8] Nyarko, K., I., Agyeman-Duah, M., O., and Asimah, V. "Measuring Customer Loyalty Using Retention, Advocacy and Patronage as Key Denominators," International Journal of Scientific and Research Publications, Vol. 6, Issue 2, pp 375-379, February 2016 